\title{
Dose Dependent Synergism from Combination of Platinum Drugs with Curcumin against Colorectal Cancer Cell Lines
}

\author{
Hana Bali' ${ }^{1}$ Jun Qing Yu', Philip Beale², and Fazlul $\mathrm{Huq}^{3}$
}

\begin{abstract}
Introduction: Colorectal cancer is the fourth most common cause of cancer mortality. More than 41265 new cases of colorectal cancer were detected and around 15903 colorectal cancer deaths occurred in year 2014 worldwide according to the statistical study from the cancer research. Chemotherapy is still in the main stream of the management of colorectal cancer along with surgery and radiotherapy. Aim: The objective of the present study was to investigate the activity of curcumin in combination with platinum drugs against colorectal cancer models (HT-29, Caco-2, LIM-1215 and LIM-2405). Methods: $\mathrm{IC}_{50}$ values of cisplatin (Cs), oxaliplatin (Ox), and curcumin (Cur) were determined against four human colorectal cancer cell lines using MTT reduction assay. Combined drug activity was determined as a factor of sequence of administration $(0 / 0,0 / 4$ and $4 / 0 \mathrm{~h})$ and added concentrations. DNA binding and proteomics were carried out to obtain insight into molecular mechanisms of drug action. Results: Oxaliplatin in combination with curcumin produced strong synergism in the tested cell lines. Cellular accumulation study, platinum-DNA binding study and DNA damage study revealed the mechanism
\end{abstract}

Significance | This study showed synergistic drug combination and mechanistic information related to changes in protein expression.

${ }^{*}$ Correspondence: Retired Academic and Editor-in-Chief Eman Research Ltd, Journal of Angiotherapy, Canberra, Australia. Email: Fazlul.huq@bigpond.com

Editor Aman Shah Abdul Majid, Quest International University. And accepted by the Editorial Board September 10, 2020 (received for review August 18, 2020) of combined drug affects. Upregulation of K1C18, GRP78, IDHC and Cofilin-1 proteins was considered to be associated with the synergistic combined effects of Oxaliplatin with curcumin. Conclusion: $O x$ in combination Cur demonstrated very high synergism against HT-29 and Caco-2 cell lines. Synergism from Ox with Cur may be associated with greater platinum DNA binding. Proteomics revealed that the elevated expressions of K1C18, GRP78, IDHC and Cofilin1 may be responsible for the synergistic activity obtained from the combination of $\mathrm{Ox}$ with Cur.

Key Words: Colorectal cancer; platinum drugs; drug resistance, synergism; proteomics

\section{Introduction}

Cancer is the major health concern all around the world and considered as the most devastating disease of our time. Among 200 different types of diagnosed cancers, colorectal cancer is the fourth most leading cause of death among all reported cancer mortality. The incidence of colorectal cancer is higher in developed countries, comprising $75 \%$ of all cases compared to lower income regions of the world (Ferlay, Soerjomataram et al. 2015). Primary treatment methods of colorectal cancer are: surgery, cryosurgery, stereotactic body radiation therapy, radiofrequency ablation and chemotherapy. Although surgery is

\footnotetext{
Author Affiliation:

${ }^{1}$ Discipline of Pathology, Sydney Medical School, A26 - RC Mills, University of Sydney.

${ }^{2}$ Sydney Cancer Centre, Concord Hospital, Sydney, NSW 2139, Australia.

${ }^{3}$ Editor-in-Chief, Eman Research Ltd, Journal of Angiotherapy, Canberra, Australia

Please cite this article:

Hana Bali, Jun Qing Yu, Philip Beale, and Fazlul Huq. (2020). Dose dependent synergism from combination of platinum drugs with curcumin against colorectal cancer cell lines. Journal of Angiotherpay, 4(1), pages 176-193.
}

2207-8843/@ 2019 ANGIOTHERAPY, a publication of Eman Research Ltd, Australia. This is an open access article under the CC BY-NC-ND license.
(http://creativecommons. org/licenses/by-nc-nd/4.0/) (http://creativecommons.org/licenses/by-nc-nd/4.0/). 
is the gold standard for the treatment of localized colorectal cancer, chemotherapy is the treatment of choice to treat metastasized colorectal cancer patients. Currently, clinicians are use combination chemotherapeutic regimen (e.g. FOLFOX, FOLFIRI) for the treatment of advanced colorectal cancer (Holch, Ricard et al. 2017).

Epidemiological studies (more than 200) suggest that higher consumptions of fruits and vegetables which are the major sources of antioxidant phytochemicals can serve to reduce incidence of cancer (Willett and Trichopoulos 1996). Phytochemicals in combination with other chemotherapeutic drugs have been investigated against various cancer models and entered into clinical trials. Our group has published a significant number of research articles showing the combined effect of platinum drugs and phytochemicals against ovarian cancer (Yunos, Beale et al. 2011; Mazumder, Beale et al. 2012; Nessa, Beale et al. 2012; AlEisawi, Beale et al. 2013; Huq, Yu et al. 2014; Huq 2015; Arzuman, Beale et al. 2016; Alam, Yu et al. 2020). Now we have extended our research interest towards colorectal cancer models as well. In this study a well-known phytochemical, curcumin has been investigated in combination with platinum drugs (cisplatin and oxaliplatin) against colorectal cancer cell lines for the combined drug effects. Studies on DNA damage, cellular accumulation of platinum, platinum $\triangle D N A$ binding and proteomic study were carried out to identify the underlying mechanisms for the combined drug action.

\section{Materials and methods}

Chemicals: Cisplatin (Cs) was synthesized in the host laboratory using modified Dhara method (Dhara 1970). Oxaliplatin (Ox) was purchased from Sigma Aldrich, USA. Curcumin (Cur) was obtained from Sapphire Bioscience, Pty. Ltd., Australia.

Preparation of stock solutions for single drug cytotoxicity and combination study: $1 \mathrm{mM}$ solutions of Cs and Ox were prepared by dissolving $.0015 \mathrm{~g}$ and $0.0019 \mathrm{~g}$ of the respective compounds in 1 $\mathrm{mL}$ of DMF first, followed by the addition of $4 \mathrm{~mL}$ of $\mathrm{H}_{2} \mathrm{O}$. To prepare $10 \mathrm{mM}$ solution of Cur, $0.018 \mathrm{~g}$ was dissolved in $5 \mathrm{~mL}$ of ethanol. The drug solutions were serially diluted from the stock solutions with freshly prepared RPMI-1640 medium to produce a range of concentrations.

Cell culture: Human colorectal cancer cell lines HT-29, Caco-2, LIM-1215 and LIM-2405 were seeded in $25 \mathrm{~cm}^{2}$ cell culture flasks in an incubator at $37^{\circ} \mathrm{C}$ in a humidified atmosphere consisting of $5 \% \mathrm{CO}_{2}$ in air. HT-29 and Caco-2 colorectal cancer cell lines were got as gifts from Dr. Mu Yao (Department of Endocrinology, The University of Sydney, Australia). LIM-1215 and LIM-2405 cell lines were purchased from Cell Bank Australia. All the collected cell lines were maintained in logarithmic growth phase in a complete medium consisting of RPMI-1640, 10\% heat-inactivated foetal calf serum, $20 \mathrm{mM}$ Hepes, $0.11 \%$ bicarbonate, and $2 \mathrm{mM}$ glutamine.

MTT [3-(4,5-Dimethylthiazol-2-yl)-2,5-diphenyl-2H-tetrazolium bromide] reduction assay:

Antitumour activity of the platinum drugs (Cs and Ox) and phytochemical Cur against four human colorectal cancer cells either alone or in combination was determined by following established method of MTT reduction assay (Mosmann 1983). Briefly, 3500 to 4500 cells per well in RPMI-1640 medium were seeded into flat-bottomed 96-well culture plate and allowed to attach overnight. When drugs (Cs/Ox/Cur) were added alone, four different concentrations of each drug were prepared from the stock solutions and $100 \mu \mathrm{l}$ of drugs were added to equal volumes of cell culture in triplicate wells added to triplicate wells which were left in the incubator $\left(37^{\circ} \mathrm{C}, 5 \%\right.$ carbon dioxide in air, $\left.\mathrm{pH} 7.4\right)$ for 72 h. During combination studies, cells were treated with increasing concentrations of compounds at constant ratios of their $\mathrm{IC}_{50}$ values using three different sequences of administration: bolus or $0 / 0$ (platinum drug or phytochemical added at the same time), 0/4 (Cs/Ox was added first followed by Cur $4 \mathrm{~h}$ later) and 4/0 (Cur was added first followed by $\mathrm{Cs} / \mathrm{Ox} 4 \mathrm{~h}$ later). The molar concentration ratios between Cs and Cur in HT-29, Caco-2, LIM1215 and LIM-2405 cell lines were: $0.298,0.814,0.238$ and 0.597 respectively. Whereas molar concentration ratios between $\mathrm{Ox}$ and Cur in in HT-29, Caco-2, LIM-1215 and LIM-2405 cell lines were $0.029,0.128,2.18$ and 0.910 respectively. After $72 \mathrm{~h}$ of incubation of the drug treated cells and control in $5 \% \mathrm{CO}_{2}$ incubator, the medium was removed and $50 \mu \mathrm{l}$ of the MTT solution were added to each well of 96-well plate. After completion of $4 \mathrm{~h}$ incubation period, $150 \mu \mathrm{l}$ of DMSO were added to each well. The viable cells remained attached at the bottom stained with MTT as purple formazan product. The mean absorbance at $595 \mathrm{~nm}$ for each compound or drug treatment whether alone or in combination was expressed as a percentage of the untreated control well absorbance. The consequence of combined drug treatments was studied using a median effect analysis whereby a combination index (CI) was calculated from pooled data from 4 to 6 individual experiments each comprising at least three data points for each drug alone and for each drug combination. The combination index (CI) for two compounds or drugs was calculated from the following calculation based on Chou and Talalay median effect (Chou and Talalay 1984) equation:

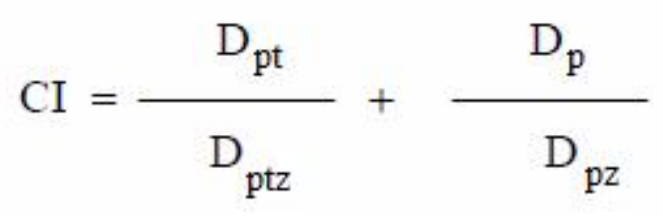


Where, Dpt refers to concentration of platinum drug required for $\mathrm{z} \%$ cell kill while in combination; Dp refers to concentration of phytochemical required for $z \%$ cell kill in combination; Dpt refers to concentration of platinum drug required for $\mathrm{z} \%$ cell kill while applied alone; Dp refers to concentration of phytochemical drug required for $\mathrm{z} \%$ cell kill while applied alone. CI values of $<1,=1$ and $>1$ indicate respectively synergism, additiveness and antagonism in combined drug action. The $C I, D_{m}$ and $r$ values were obtained automatically using Calcusyn software (V2) (Biosoft, UK). The $\mathrm{D}_{\mathrm{m}}$ sometimes reflect the values of $\mathrm{IC}_{50}$ value. The linear correlation coefficient, $r$ (where $r=1$ indicates perfect fit), of the median effect plot should be reasonably good; for the cell culture system, $r$ should be greater than 0.95 ( $r>0.95)$.

Cellular accumulation of Platinum: For cellular accumulation study, stock solutions of the compounds were again prepared (Cs: $1 \mathrm{mM}$; Oxa: $0.63 \mathrm{mM}$; Cur: $0.71 \mathrm{mM}$ ). Exponentially growing HT29 and CACO-2 colorectal cancer cells in $4.75 \mathrm{~mL} \mathrm{10 \%} \mathrm{FCS/RPMI}$ medium (cell density $=50 \times 10^{4}$ cells $\mathrm{mL}-1$ ) were seeded into cell culture dishes and allowed to attach overnight. While drugs were added in combination, $125 \mu \mathrm{L}$ of Cs/Ox and $125 \mu \mathrm{L}$ of Cur was added to the cells. But in case of Cs and Ox alone treatment $125 \mu \mathrm{L}$ of drug and $125 \mu \mathrm{L}$ of each medium were added. The above treatments were conducted in two sets, one for cellular accumulation studies and another one for platinum and platinum-DNA binding studies. The cells containing the drugs were incubated for $24 \mathrm{~h}$, at the end of which cell monolayers were trypsinized and cell suspension $(10 \mathrm{~mL})$ was transferred to a centrifuge tube and spun at 3,500 rpm for $2 \mathrm{~min}$ at $4^{\circ} \mathrm{C}$. The cells were washed twice with ice-cold phosphate-buffered saline. At least three independent experiments were performed. Following incubation with compounds singly and in binary combination, cell pellets were suspended in $0.5 \mathrm{~mL}$ of $1 \%$ Triton-X, held on ice then sonicated for $30 \mathrm{~min}$. Total intracellular platinum contents were determined by graphite furnace (AAS) using a Varian SpectrAA20 with a GTA 96 atomic absorption spectrophotometer.

Platinum $₫ D N A$ binding study: Drug treatment and cell collection procedure was same as described for cellular platinum accumulation study. To extract pure genomic DNA, the protocol described for cultured animal cell in the KIT was exactly followed. Briefly, the pellet was resuspended with ACL solution buffer and mixed with protenase $\mathrm{K}$ and then incubated at $55^{\circ} \mathrm{C}$ for $10 \mathrm{~min}$. RNase A was added and vortexed; incubated at room temperature for 5 minutes and then centrifuged for 5 minutes at 12,000 rpm for 5 minutes. Supernatant was taken and mixed with $A B$ solution for 2 minutes. After discarding flow through, wash solution was added and spun at 10,000 rpm for 1 minute. The columns were put into Eppendorf tubes and elution buffer was added and incubated at $50^{\circ} \mathrm{C}$ for 2 minutes. The tubes were centrifuged $10,000 \mathrm{rpm}$ for 2 minutes to elute the DNA and then quantified UV absorption spectrophotometer at $260 \mathrm{~nm}$ (Varian Cary 1E UV-Visible with Varian Cary Temperature Controller). A260/A280 ratio between 1.75 and 1.8 for all samples ensures high purity of DNA. The DNA concentration was calculated according to the following equation: concentration $=$ absorbance at $260 \mathrm{~nm} \times 50 \mathrm{ng} / \mu \mathrm{l}$. Platinum content was determined using graphite furnace AAS.

DNA damage study using agarose gel electrophoresis: The protocol for extracting DNA was same as mentioned for Platinum®DNA binding study. During gel electrophoresis, 1\% agarose gel was prepared and gently transferred into the tray with comb placed in position, left at room temperature for $45 \mathrm{~min}$ to solidify (Stellwagen 1998). $250 \mu \mathrm{L}$ of ethidium bromide was added in both side of electrophoresis chamber. Entire gel was dipped into the electrophoresis chamber using TAE working buffer. Estimated volume of DNA sample (measured as corresponding to $0.2 \mu \mathrm{g}$ of DNA) was mixed with required volume of $\mathrm{mQ}$ water to make the total of $18 \mu \mathrm{l}$, followed by mixing with $2 \mu \mathrm{l}$ of bromophenol blue chromatogram. Electrophoresis was accomplished at $120 \mathrm{~V}$ for 2 hours. UV lamp was used to visualize the bands and the images were taken by Kodak Gel Logic 100 imaging system (GL 100).

Proteomic study: Proteomic studies were carried out to identify the proteins that were responsible for the drug actions either alone or in combination in Caco-2 cell line. The cells were cultured in 50 $\mathrm{cm}^{2}$ petri dishes to produce the concentration of $10^{6}$ cells/dish. Caco- 2 cell line was treated with $\mathrm{Ox}$ alone, Cur alone and $\mathrm{Ox}+\mathrm{Cur}$ $(0 / 0)$ at $\mathrm{IC}_{50}$ concentrations. Control cells were treated will the medium only. Following $24 \mathrm{~h}$ of incubation period after drug treatment, cell pellets were collected through washing with PBS and centrifugation. The pellets were lysed using cell lysis buffer, $1^{\text {st }}$ dimensional electrophoresis was done using non-linear ReadyStrip ${ }^{\text {Tx }}$ IPG Strip in Protean i12 IEF (Isoelectric focusing) cell unit. $2^{\text {nd }}$ dimensional gel electrophoresis (SDS-PAGE) was conducted by using 4-20\% SDS Criterion ${ }^{\mathrm{Tm}} \mathrm{TGX}^{\mathrm{Tm}}$ pre-cast gels in a Criterion Dodeca ${ }^{\text {Tim }}$ cell separation unit (BIO-RAD, Australia) at constant $200 \mathrm{~V}$ for $100 \mathrm{~min}$ in a Trisglycine- $\mathrm{HCl}$ buffer system. The detailed method has been described elsewhere (Al-Eisawi, Beale et al. 2016; Alam, Yu et al. 2020). The gel images were taken by ChemiDoc ${ }^{\mathrm{Ts}}$ MP Imaging system (BIO-RAD, Australia) and spots were analysed by using Melanie version 7.0 software (GeneBio, Switzerland). A 1.5-fold change in the expression of a protein across the matched groups was used as the indicative point for significant expression. Analysis of variance (ANOVA), a statistical tool used to detect differences between experimental group means, was performed using a target significance level of 0.05 .

Mass spectral characterization of differentially expressed proteins: Bio-Safe Coomassie Stain was used for staining the spots before 
excision from 2-D gels. Destaining of the spots was done by using

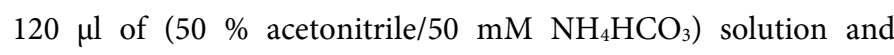
digestion of spots was performed by trypsin. The obtained peptides were extracted with $0.1 \%$ trifluoroacetic acid (TFA) then extracted and concentrated by C18 zip-tips (Millipore, $\mu$-C18, P10 size) on Xcise (Proteome Systems). Matrix assisted laser desorption ionisation mass spectrometry (MALDI-MS) was performed with 4800 plus MALDI TOF/TOF Analyser (AB Sciex). Detailed procedure has been described in our earlier article (AlEisawi, Beale et al. 2016). The data on peptides masses were analysed using database search program Mascot (Matrix Science Ltd, London, UK). The peak lists were searched against Homo sapiens entries in the SwissProt database.

\section{Results}

Anticancer activity of single drugs: The results of the antitumour activity of tested compounds (Cs, Ox and Cur) against four human colorectal cancer cell lines obtained from MTT reduction assay are presented Figure 1. It is evident from Figure 1 that, Ox produced highest anticancer activity among the tested compounds against all tested colorectal cell lines except LIM-2405 cell line where Cis showed the greatest cell kill. Although Cur showed the lowest antitumour activity among the investigated compounds, the phytochemical still presented significant anticancer activity against the tested cell lines.

Anticancer activity of the drugs in combination: Combined drug effect as a function of sequence of administration and added concentrations from selected combinations was determined using dose response curves and combination indices (CI). Dose response curves provide qualitative measure of combined drug actions while CI values represent the same in a quantitative manner. Figure $2 \mathrm{a}$, Figure $2 \mathrm{~b}$, Figure $2 \mathrm{c}$ and Figure $2 \mathrm{~d}$ present the dose response curves obtained from combinations of Cs with Cur against HT-29, Caco-2, LIM-1215 and LIM-2405 cell lines respectively. Figure 3a, Figure $3 b$, Figure $3 c$ and Figure $3 d$ present the dose response curves obtained from combinations of $\mathrm{Ox}$ with Cur against HT-29, Caco-2, LIM-1215 and LIM-2405 cell lines respectively. Table 1 and Table 2 give dose-effect parameters in terms of median-effect dose, shape (sigmoidicity), conformity (linear correlation coefficient), represented as Dm, $\mathrm{m}$ and $\mathrm{r}$ respectively. $\mathrm{ED}_{50}, \mathrm{ED}_{75}$ and $\mathrm{ED}_{90}$ represents the combined drug concentration required for $50 \%, 75 \%$ and $90 \%$ cell kill, respectively.

It can be seen from Figure $2 \mathrm{a}-2 \mathrm{~d}$ and Table 1 that, when Cs was administered in combination with Cur against the colorectal tumour models, strong synergism was found in LIM-1215 cell line and LIM-2405 cell lines depending on concentrations and sequence of administrations. In LIM-1215 cell line, stronger synergism was observed at lower concentrations than at higher concentrations. But only $0 / 4$ and $4 / 0$ sequences showed synergism against LIM-2405 cell line, with greater synergism being observed at lower concentrations. On the contrary, antagonism was predominant in HT-29 and CACO-2 cell lines except at ED 90 level in HT-29 model where moderate synergism was evident.

Figure 3a-3d and Table 2 show that when Ox was administered in combination with Cur, synergism was found against all tested colorectal tumour models at all added concentrations and sequences of administrations. A general trend of increasing synergistic effect was evidenced with the increase in added concentration for all sequences of administrations against the colorectal cancer models. Stronger synergism was demonstrated against Caco-2 tumour model compared to other cell lines.

Cellular accumulation and Platinum $\triangle D N A$ binding study study: The study was conducted with selected combinations of platinum drugs $(\mathrm{Cs} / \mathrm{Ox}$ ) and the phytochemical (Cur) to find out the relationship between combined drug action and cellular accumulation of platinum and platinum $\triangle \mathrm{DNA}$ binding using two human colorectal cell lines (HT-29 and Caco-2). The results obtained from the study are given in Table 3. It can be seen that synergistic combinations produced higher platinum-DNA binding compared to that of single administration of Cs or Ox in both tested colorectal cell lines. However, cellular accumulation study did not show any correlation with the accumulation of platinum and synergism from combination.

DNA damage study: The study was also conducted using drugs administered alone and in selected combinations to understand the correlation between DNA damage and drug effects (alone/combination). The results of the study are given in Table 4. Increase in mobility or decrease in intensity in the cellular DNA band of the drug treated cell compared to untreated blank indicates the qualitative damage to DNA. It can be seen from the study that synergistic combination $(\mathrm{Ox}+\mathrm{Cur} 4 / 0)$ caused the highest damage to DNA in both HT-29 and Caco-2 cells. Whereas additive to antagonistic combinations caused less damage to DNA. The results indicate that death of cancer cell was due to interactios of the compounds with DNA so that synergism obtained from the combination of platinums (Cs/Ox) with Cur was positively correlated with DNA damage.

Proteomics: The study was conducted to get mechanistic information concerning changes in expression of proteins observed in Caco-2 colorectal cancer cell lines after treatment with Ox alone, Cur alone and combination of Ox with Cur (0/0). Among 195 protein spots identified in reference (untreated) Caco2 gels, 80 spots underwent significant changes in expression in Cur alone treated gel. The number of spots experiencing significant changes in expression with Ox alone treatments were 148. After treatment with $\mathrm{Ox}$ with Cur (bolus) 86 protein spots underwent significant altered expression. Finally, 24 spots (which met the 




Figure 1 | Cytotoxicity of the single drugs against colorectal cancer cell lines (bars on top indicate errors in measurements) prevention.

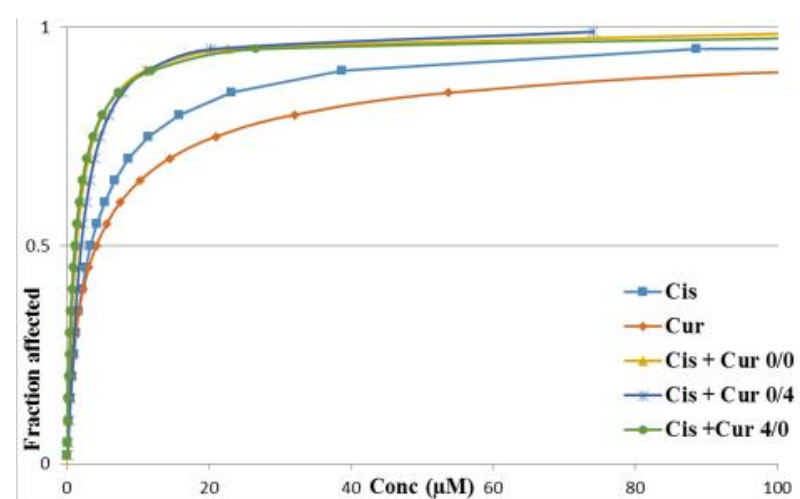

2-A



2-C

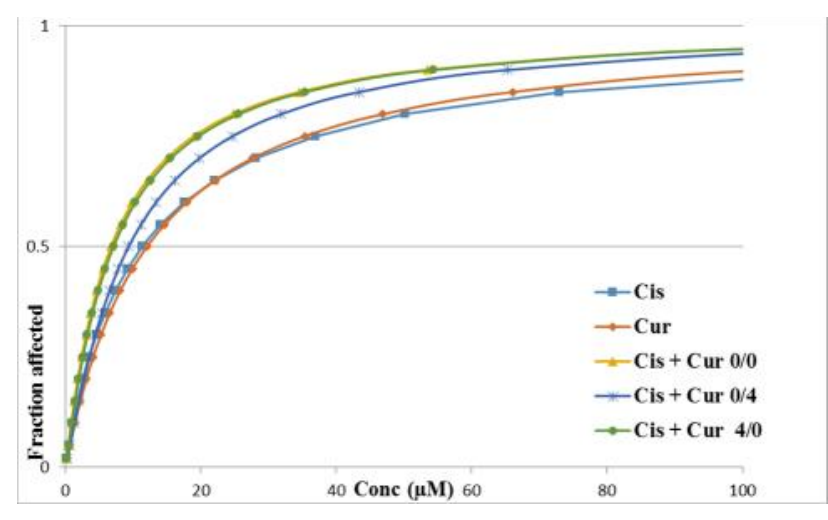

2-B

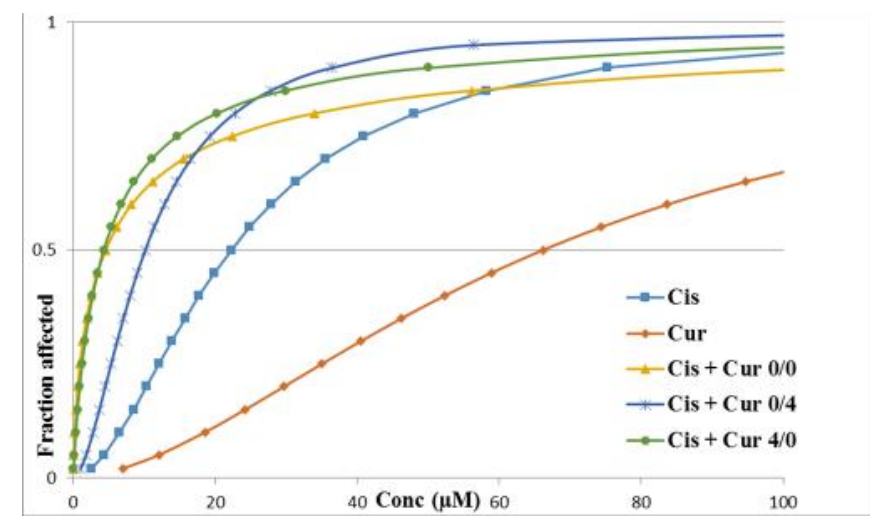

2-D

Figure 2 | Dose response curves obtained from combination of Cs with Cur. 2a: HT-29 cell line; 2b: Caco-2 cell line; 2c: LIM-1215 cell line; $2 \mathrm{~d}$ : LIM-2405 cell line. 


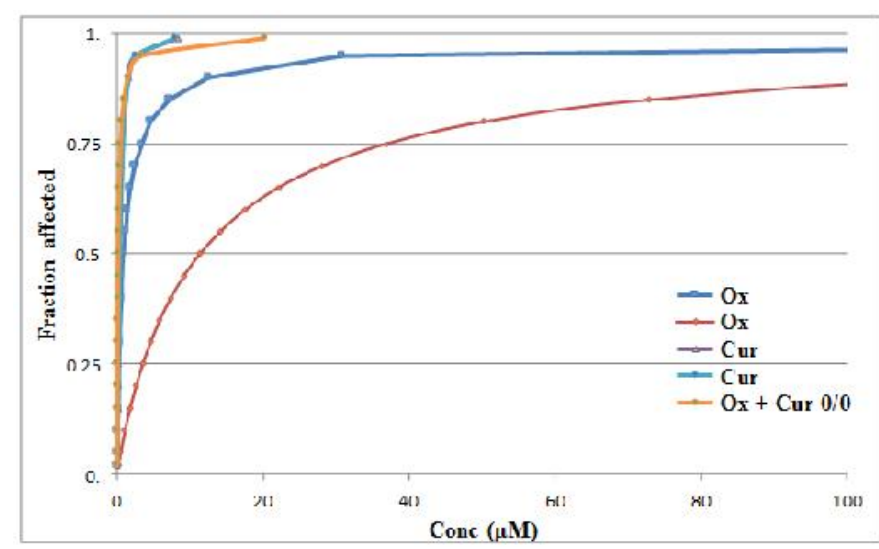

3-A

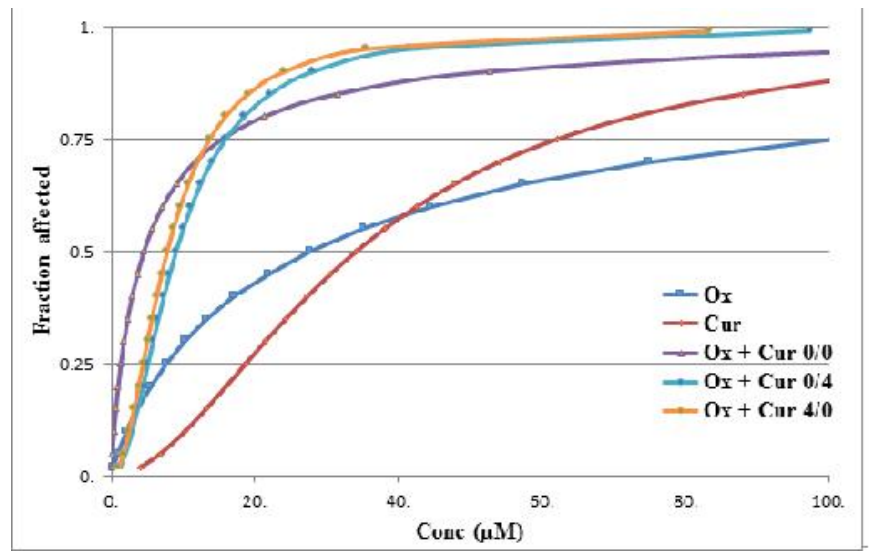

3-C

Figure 3 | Dose response curves obtained from combination of Ox with Cur. 3a: HT-29 cell line; 3b: Caco-2 cell line; 3c: LIM-1215 cell line; 3d: LIM-2405 cell line

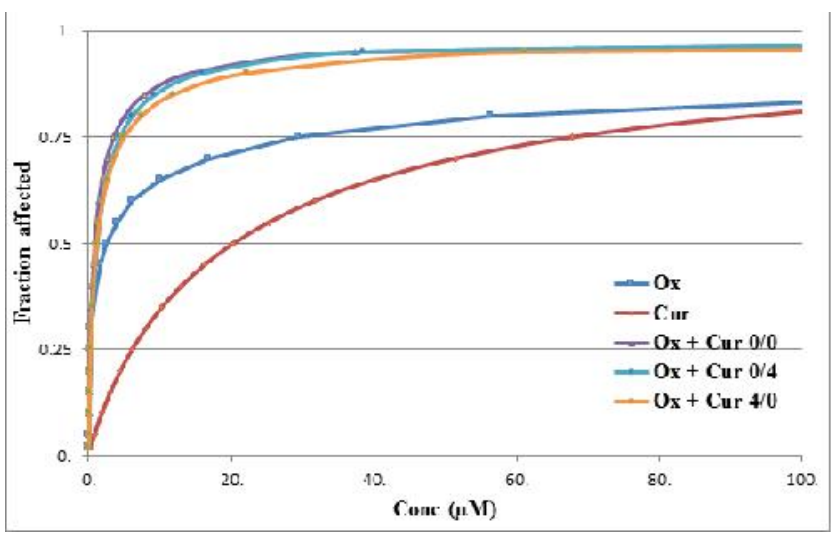

3-B

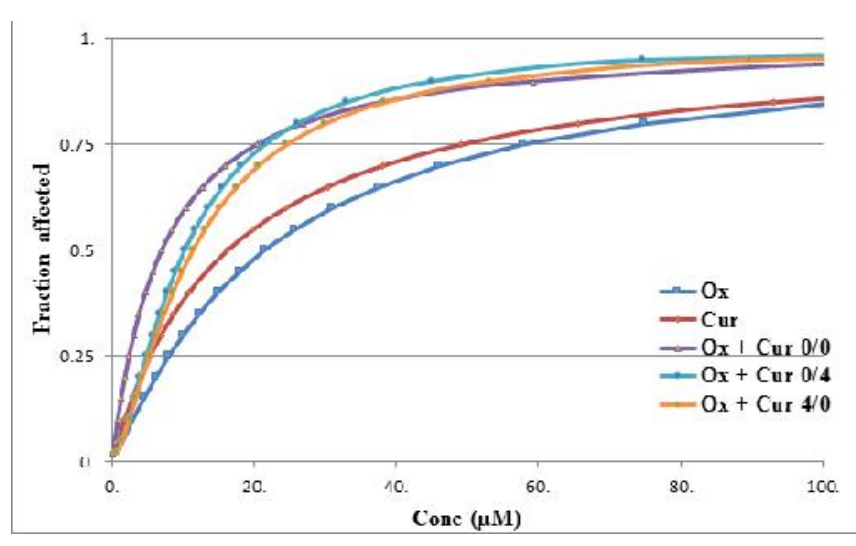

3-D 
Table 1 | Dose-effect parameters applying to combinations of cisplatin with curcumin in the colorectal cancer cell lines (results are based on at least triplicate independent experiments)

\begin{tabular}{|c|c|c|c|c|c|c|c|c|}
\hline \multirow{3}{*}{ Cell line } & \multirow{3}{*}{ Drug or drug combination } & \multirow{3}{*}{ Sequence (h) } & \multirow{2}{*}{\multicolumn{3}{|c|}{ CI values at }} & \multirow[b]{3}{*}{$\mathrm{D}_{\mathrm{m}}$} & \multirow[b]{3}{*}{$\mathrm{m}$} & \\
\hline & & & & & & & & \multirow[b]{2}{*}{$\mathrm{r}$} \\
\hline & & & $\mathrm{ED}_{50}$ & $\mathrm{ED}_{75}$ & $\mathrm{ED}_{90}$ & & & \\
\hline \multirow{5}{*}{ HT-29 } & Cs & & NA & NA & NA & 3.38 & 0.90 & 0.99 \\
\hline & Cur & & NA & NA & NA & 4.15 & 0.67 & 0.96 \\
\hline & $\mathrm{Cs}+\mathrm{Cur}$ & $0 / 0$ & 1.51 & 0.97 & 0.65 & 1.33 & 1.04 & 0.98 \\
\hline & $\mathrm{Cs}+\mathrm{Cur}$ & $0 / 4$ & 2.26 & 1.20 & 0.665 & 2.00 & 1.27 & 0.99 \\
\hline & $\mathrm{Cs}+\mathrm{Cur}$ & $4 / 0$ & 1.27 & 0.92 & 0.69 & 1.12 & 0.93 & 0.98 \\
\hline \multirow{5}{*}{ Caco-2 } & Cs & & N/A & N/A & N/A & 11.34 & 0.93 & 0.98 \\
\hline & Cur & & N/A & N/A & N/A & 12.05 & 1.02 & 0.99 \\
\hline & $\mathrm{Cs}+\mathrm{Cur}$ & $0 / 0$ & 1.05 & 0.95 & 0.86 & 6.74 & 1.06 & 1.00 \\
\hline & $\mathrm{Cs}+\mathrm{Cur}$ & $0 / 4$ & 1.45 & 1.24 & 1.06 & 9.34 & 1.13 & 1.00 \\
\hline & Cs+Cur & $4 / 0$ & 1.11 & 0.99 & 0.88 & 7.10 & 1.08 & 1.00 \\
\hline \multirow{5}{*}{ LIM-1215 } & Cs & & N/A & N/A & N/A & 22.23 & 1.80 & 0.99 \\
\hline & Cur & & N/A & N/A & N/A & 66.17 & 1.73 & 0.93 \\
\hline & $\mathrm{Cs}+\mathrm{Cur}$ & $0 / 0$ & 0.22 & 0.59 & 1.57 & 4.57 & 0.69 & 0.95 \\
\hline & $\mathrm{Cs}+\mathrm{Cur}$ & $0 / 4$ & 0.49 & 0.51 & 0.52 & 10.14 & 1.72 & 0.99 \\
\hline & $\mathrm{Cs}+\mathrm{Cur}$ & $4 / 0$ & 0.21 & 0.39 & 0.72 & 4.30 & 0.89 & 1.00 \\
\hline \multirow{5}{*}{ LIM-2405 } & Cs & & N/A & N/A & N/A & 12.94 & 1.73 & 0.93 \\
\hline & Cur & & N/A & N/A & N/A & 29.32 & 0.69 & 0.96 \\
\hline & $\mathrm{Cs}+\mathrm{Cur}$ & $0 / 0$ & 0.74 & 1.66 & 4.00 & 7.62 & 0.70 & 0.97 \\
\hline & $\mathrm{Cs}+\mathrm{Cur}$ & $0 / 4$ & 0.30 & 0.38 & 0.51 & 3.08 & 1.10 & 0.98 \\
\hline & $\mathrm{Cs}+\mathrm{Cur}$ & $4 / 0$ & 0.28 & 0.41 & 0.65 & 2.89 & 0.96 & 0.98 \\
\hline
\end{tabular}

Table 2 | Dose-effect parameters applying to combinations of oxaliplatin with curcumin in the colorectal cell lines (results are based on at least triplicate independent experiments)

\begin{tabular}{|c|c|c|c|c|c|c|c|c|}
\hline \multirow{3}{*}{ Cell line } & \multirow{3}{*}{ Drug or drug combination } & \multirow{3}{*}{ Sequence (h) } & \multirow{2}{*}{\multicolumn{3}{|c|}{ CI values at }} & \multirow[b]{3}{*}{$\mathrm{D}_{\mathrm{m}}$} & \multirow[b]{3}{*}{$\mathrm{m}$} & \\
\hline & & & & & & & & \multirow[b]{2}{*}{$\mathrm{r}$} \\
\hline & & & $\mathrm{ED}_{50}$ & $\mathrm{ED}_{75}$ & $\mathrm{ED}_{90}$ & & & \\
\hline \multirow{5}{*}{ HT-29 } & Ox & & NA & NA & NA & 0.86 & 0.82 & 0.98 \\
\hline & Cur & & NA & NA & NA & 0.31 & 1.39 & 1.00 \\
\hline & $\mathrm{Ox}+\mathrm{Cur}$ & $0 / 0$ & 0.35 & 0.21 & 0.12 & 0.31 & 1.39 & 1.00 \\
\hline & $\mathrm{Ox}+\mathrm{Cur}$ & $0 / 4$ & 0.44 & 0.24 & 0.13 & 0.38 & 1.52 & 1.00 \\
\hline & $\mathrm{Ox}+\mathrm{Cur}$ & $4 / 0$ & 0.16 & 0.14 & 0.12 & 0.14 & 0.92 & 1.00 \\
\hline \multirow{5}{*}{ Caco-2 } & Ox & & $\mathrm{N} / \mathrm{A}$ & N/A & $\mathrm{N} / \mathrm{A}$ & 2.49 & 0.44 & 1.00 \\
\hline & Cur & & $\mathrm{N} / \mathrm{A}$ & N/A & $\mathrm{N} / \mathrm{A}$ & 20.28 & 0.91 & 1.00 \\
\hline & $\mathrm{Ox}+\mathrm{Cur}$ & $0 / 0$ & 0.35 & 0.13 & 0.05 & 0.86 & 0.78 & 0.98 \\
\hline & $\mathrm{Ox}+\mathrm{Cur}$ & $0 / 4$ & 0.49 & 0.16 & 0.05 & 1.21 & 0.85 & 0.98 \\
\hline & $\mathrm{Ox}+\mathrm{Cur}$ & $4 / 0$ & 0.46 & 0.18 & 0.08 & 1.13 & 0.74 & 1.00 \\
\hline \multirow{5}{*}{ LIM-1215 } & Ox & & N/A & N/A & $\mathrm{N} / \mathrm{A}$ & 27.70 & 0.85 & 0.92 \\
\hline & Cur & & $\mathrm{N} / \mathrm{A}$ & N/A & $\mathrm{N} / \mathrm{A}$ & 34.12 & 1.83 & 0.93 \\
\hline & $\mathrm{Ox}+\mathrm{Cur}$ & $0 / 0$ & 0.45 & 0.70 & 1.16 & 4.55 & 0.90 & 0.96 \\
\hline & $\mathrm{Ox}+\mathrm{Cur}$ & $0 / 4$ & 0.90 & 0.72 & 0.62 & 9.04 & 1.93 & 0.99 \\
\hline & $\mathrm{Ox}+\mathrm{Cur}$ & $4 / 0$ & 0.78 & 0.62 & 0.53 & 7.79 & 1.94 & 0.97 \\
\hline \multirow{4}{*}{ LIM-2405 } & Ox & & N/A & N/A & N/A & 21.45 & 1.11 & 0.95 \\
\hline & Cur & & $\mathrm{N} / \mathrm{A}$ & N/A & $\mathrm{N} / \mathrm{A}$ & 16.26 & 0.99 & 0.92 \\
\hline & $\mathrm{Ox}+\mathrm{Cur}$ & $0 / 0$ & 0.72 & 0.73 & 0.74 & 6.98 & 1.03 & 0.95 \\
\hline & $\mathrm{Ox}+\mathrm{Cur}$ & $0 / 4$ & 1.05 & 0.77 & 0.57 & 10.22 & 1.48 & 0.99 \\
\hline
\end{tabular}


Table 3 | Cellular accumulation of platinum and platinum-DNA binding (based on triplicate measurements).

\begin{tabular}{|c|c|c|c|c|}
\hline Cell line & Sample & Combined Effect at $\mathrm{ED}_{5}$ & ${ }_{0} \mathrm{Pt}\left(\mathrm{nmol} / 5 \times 10^{6}\right.$ cell $)$ & Pt (nmol)/DNA(mg) \\
\hline \multirow{5}{*}{ HT-29 } & (alone) & Not applicable & $4.27 \pm 0.04$ & $1.00 \pm 0.08$ \\
\hline & Cs with Cur $(4 / 0)$ & Additive to antagonistic & $4.90 \pm 0.26$ & $0.93 \pm 0.15$ \\
\hline & Ox (alone) & Not applicable & $0.09 \pm 0.28$ & $0.20 \pm 0.03$ \\
\hline & Ox with Cur $(0 / 0)$ & Synergistic & $0.08 \pm 0.01$ & $0.26 \pm 0.15$ \\
\hline & Ox with Cur $(4 / 0)$ & Synergistic & $0.09 \pm 0.22$ & $0.24 \pm 0.04$ \\
\hline \multirow{4}{*}{ Caco-2 } & Cs (alone) & Not applicable & $2.02 \pm 0.03$ & $1.28 \pm 0.14$ \\
\hline & Cs with Cur $(4 / 0)$ & Additive to antagonistic & $3.52 \pm 0.03$ & $1.55 \pm 0.27$ \\
\hline & Ox (alone) & Not applicable & $0.27 \pm 0.3$ & $0.19 \pm 0.50$ \\
\hline & Ox with Cur $(0 / 0)$ & Synergistic & $0.09 \pm 0.19$ & $0.17 \pm 0.12$ \\
\hline
\end{tabular}

Table 4 | DNA mobility and fluorescence obtained from interactions of the compounds with DNA (Based on triplicate measurements).

\begin{tabular}{|l|l|l|l|}
\hline Bands & Combined drug action & Mobility $(\mathbf{m m})$ & Net Intensity \\
\hline HT-Blank & N/A & 3.96 & 49801.49 \\
\hline HT-Cs & N/A & 3.7 & 45927.49 \\
\hline HT-Cs + Cur (4/0) & Additive to antagonistic & 3.79 & 39748.15 \\
\hline HT-Ox & N/A & 3.79 & 32815.53 \\
\hline HT-Ox + Cur (4/0) & Synergistic & 4.13 & 6273.96 \\
\hline HT-Cur & N/A & 4.46 & 10979.88 \\
\hline CA-Blank & N/A & 5.8 & 16623 \\
\hline CA-Cs & N/A & 5.21 & 13041.2 \\
\hline CA-Cs + Cur (4/0) & Additive to antagonistic & 5.29 & 9644 \\
\hline CA-Ox & N/A & 5.04 & 23210.5 \\
\hline CA-Ox + Cur (4/0) & Synergistic & 5.13 & 16467.5 \\
\hline CA- Cur & N/A & 5.13 & \\
\hline
\end{tabular}



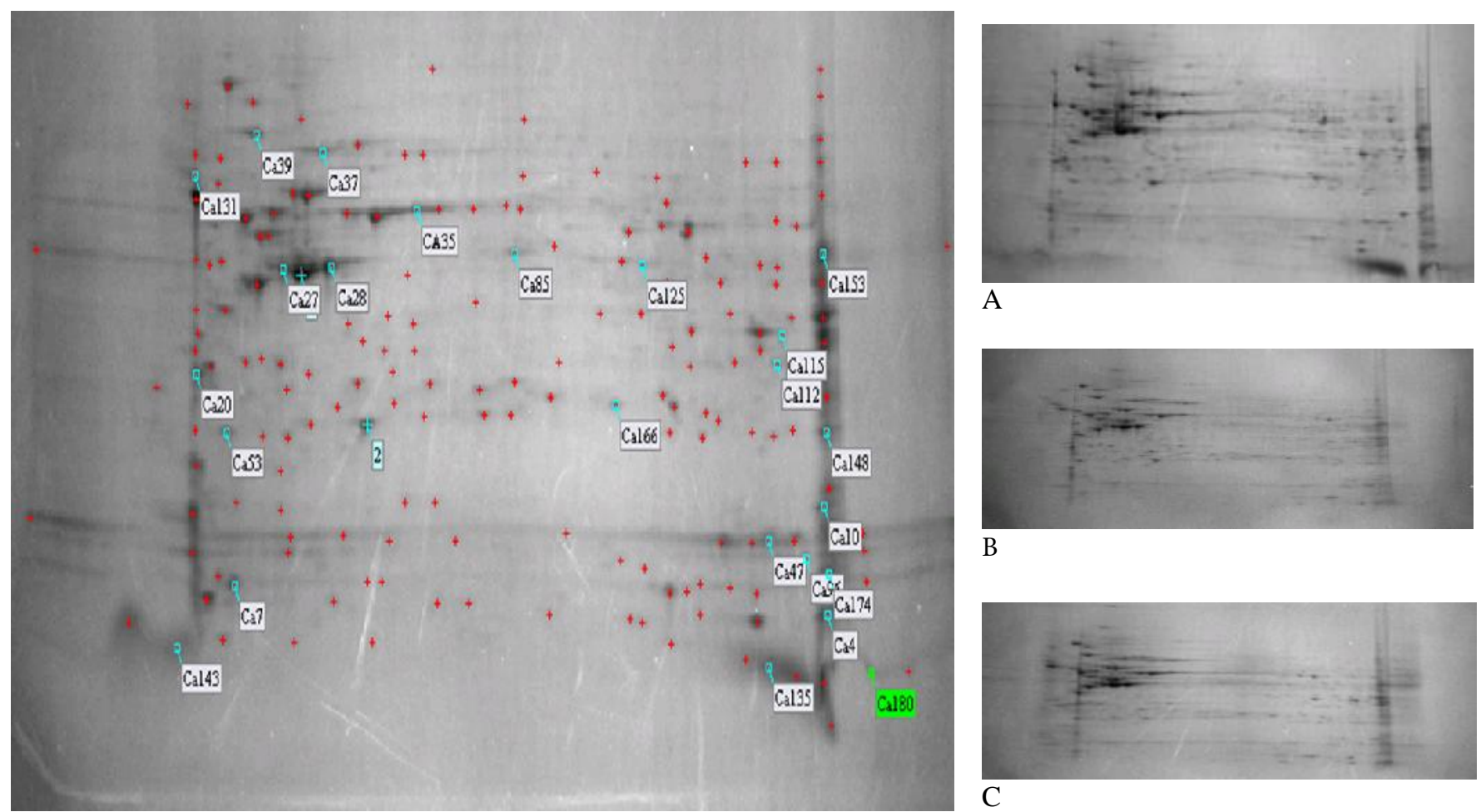

A

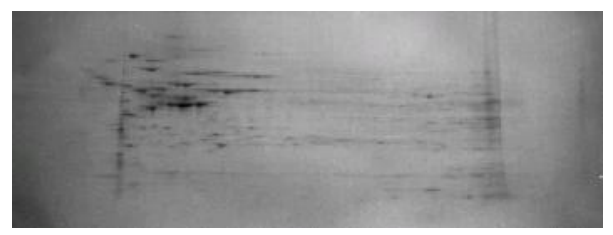

B

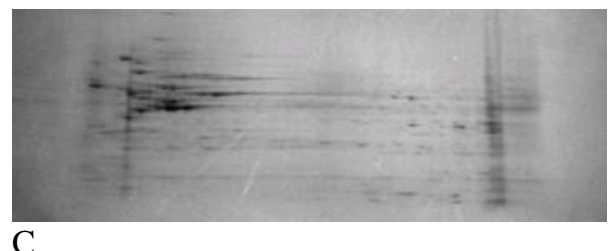

C

Figure 4 | Two dimensional gel images (a-c) of treated Caco-2 gels (A) Ox alone treated Caco-2 gel; (B) Cur alone treated CACO2 gel; (C) Ox with Cur (bolus) treated Caco-2 gel

Table 5 | Selected protein spots displaying changes in expression as applied to CACO-2 cell

\begin{tabular}{|c|c|c|c|}
\hline $\begin{array}{c}\text { Match } \\
\text { ID }\end{array}$ & Ox alone & Cur alone & Ox with Cur (0/0) \\
\hline Ca35 & SDR & Up-regulated & Up-regulated \\
\hline Ca37 & SUR & Up-regulated & Up-regulated \\
\hline Ca39 & Up-regulated & Up-regulated & Up-regulated \\
\hline Ca53 & Down-regulated & Up-regulated & Not changed \\
\hline Ca85 & SUR & Down-regulated & Up-regulated \\
\hline Ca125 & Up-regulated & SUR & Up-regulated \\
\hline Ca166 & SUR & Up-regulated & \\
\hline
\end{tabular}

SDR denotes slightly downregulated and SUR denotes slightly upregulated 
Table 6 | Proteins from CACO-2 cell lines characterized (MALDI-MASS analysis)

\begin{tabular}{|c|c|c|c|c|}
\hline Match ID & Short name & Full Name & Mass (Da)/pI & $\begin{array}{l}\text { Mascot score and } \\
\text { Sequence coverage } \\
(\%)\end{array}$ \\
\hline Ca35 & $\mathrm{K} 2 \mathrm{CB}$ & $\begin{array}{l}\text { Keratin, type II } \\
\text { cytoskeletal } 8\end{array}$ & $53671 / 4.95$ & 256 and 19 \\
\hline $\mathrm{Ca} 37$ & HSP7C & $\begin{array}{l}\text { Heat shock cognate } \\
71 \mathrm{kDa} \text { protein }\end{array}$ & $70854 / 5.37$ & 536 and 24 \\
\hline Ca39 & GRP78 & $\begin{array}{l}78 \mathrm{kDa} \text { glucose- } \\
\text { regulated protein }\end{array}$ & $72288 / 5.07$ & 588 and 27 \\
\hline $\mathrm{Ca} 53$ & PSB6 & $\begin{array}{l}\text { Proteasome subunit } \\
\text { beta type-6 }\end{array}$ & $25341 / 4.80$ & 62 and 10 \\
\hline Ca85 & COF1 & Cofilin-1 & $18491 / 8.22$ & 138 and 31 \\
\hline Ca125 & IDHC & $\begin{array}{l}\text { Isocitrate } \\
\text { dehydrogenase } \\
\text { [NADP] cytoplasmic }\end{array}$ & $46630 / 6.53$ & 130 and 16 \\
\hline Ca166 & $\mathrm{K} 1 \mathrm{C} 18$ & $\begin{array}{l}\text { Keratin, type I } \\
\text { cytoskeletal } 18\end{array}$ & $48029 / 6.36$ & 345 and 4 \\
\hline
\end{tabular}

\section{Discussion}

Combination therapy can have significant advantage over monotherapy by improving the efficacy and reducing the side effects. However, most of the combination therapy currently being used (e.g. chemotherapy in combination with monoclonal antibody, chemotherapy in combination with mRNA, two or more chemotherapeutics in combination) suffers from increase in treatment cost (Lu, Lu et al. 2013). Combining phytochemicals having anticancer potential with chemotherapeutic drug might provide cost-effective solution of drug resistance in cancer. Of note, sequence of administered chemotherapeutic drugs has been implicated in combined drug actions (Levis, Pham et al. 2004). In this study binary combination of platinum drugs (Cs/Ox) and phytochemical Cur have been investigated using three different sequences of administration and concentrations against colorectal cancer models. The results of the combination study have been given in Table 1 and Table 2. It can be concluded from the results that combination of Ox with Cur is better in cell kill than that of Cs with Cur against studied four colorectal cancer models. Higher concentrations have shown greater synergism in the combination of Ox with Cur but the effect is converse in case of Cs with Cur. Previous studies from our group against ovarian cancer models (including cisplatin and picoplatin resistant A2780 cell lines) also revealed synergism from the combination of cisplatin and curcumin (Yunos, Beale et al. 2011; Nessa, Beale et al. 2012).
Younos et al. also reported that the observed synergism from the combination of cisplatin and curcumin is stronger at $\mathrm{ED}_{50}$ levels compared to that of $\mathrm{ED}_{75}$ and $\mathrm{ED}_{90}$ levels. Similarly, oxaliplatin in combination with curcumin also produced sequenced dependent synergism against ovarian tumour models. Sequenced combination of curcumin and platinum drugs with curcumin administered first and platinum drug $2 \mathrm{~h}$ later was found to show more pronounced synergistic effect against three ovarian cancer cells (Nessa, Beale et al. 2012). Another group also noticed significant synergism from combination of curcumin with cisplatin and oxaliplatin against 2008 and C13 ovarian cancer cell lines (Montopoli, Ragazzi et al. 2009). Moreover, curcumin and carboplatin in combination synergistically inhibited apoptosis and metastasis against lung cancer (Kang, Kang et al. 2015).

A number of studies against CRC models also demonstrated synergism from combinations of curcumin with platinum drugs. Oxaliplatin in combination with liposomal curcumin showed significant synergism during in vitro and in vivo xenograft model study using Lovo and Colo-205 colorectal cancer cells (Li, Ahmed et al. 2007). Another in vitro and in vivo model study using HCT116 cell lines reported that curcumin in combination with oxaliplatin reduces the chemoresistance towards oxaliplatin (Howells, Sale et al. 2011). Curcumin in combination with camptothecin also exhibited strong synergism against a colorectal cancer model (Xiao, Si et al. 2015). In an animal model study using 
FOLFOX resistant HT-29 and HCT-116 cancer cells, curcumin in combination with dasatinib showed inhibition of tumour growth, metastasis and colonosphere formation. The combination drug therapy significantly decreased the number of cancer stem cells by reducing CD133, CD44, CD166 and ALDH (Nautiyal, Kanwar et al. 2011). The mechanism behind the synergistic effects from combination of curcumin with platinum drugs was reported to be associated with the down regulation of matrix metalloproteinases (MMP-2 and MMP-9), BCL-2, NF- $\kappa$ B as well as upregulation of caspases (caspase-3 and caspase-9) and p53 (Kang, Kang et al. 2015).

To reach into the targets to impart antitumour activity, drugs must enter the cell while one of the key mechanisms for the development of resistance against platinum based anticancer drugs is to decrease the influx of the drugs into the cell. Another important mechanism is to increase the efflux of platinums from the cell (Zhu, Shanbhag et al. 2017). In both cases, outcome is reduced accumulation of platinums to reach into the target DNA to show its antitumour activity (Yu, Yang et al. 2015). Cellular accumulation study was conducted with the idea that: synergistic and additive treatments would cause increased cellular accumulation of platinum or at least would not reduce the accumulation; and antagonistic treatment might cause lower cellular accumulation of platinum. But in the present study, synergistic combinations of Ox with Cur (Bolus and 4/0) against HT-29 and Caco-2 cell line did not show increase in cellular platinum accumulation. However, synergistic combined treatments of Ox with Cur using bolus and 4/0 administration demonstrated 1.2 to 1.3 times greater extent of platinum $\triangle \mathrm{DNA}$ binding than Ox alone treatment in HT-29 cell line. The results suggest that synergism attained from the combination of $\mathrm{Ox}$ with Cur in this study is directly relate to the extent of platinum $\triangle \mathrm{DNA}$ binding.

Proteomics revealed seven proteins e.g. Keratin, type II cytoskeletal 8 (K2CB); Keratin, type I cytoskeletal 18 (K1C18); Heat shock cognate $71 \mathrm{kDa}$ protein (HSP7C); $78 \mathrm{kDa}$ glucose regulated protein (GRP78); Proteasome subunit beta type-6 (PSB6); Isocitrate dehydrogenase [NADP] cytoplasmic (IDHC) and Cofilin1 which underwent significant altered expression after drug treatments and considered to be associated with drug actions either alone or in combination.

Keratin, type II cytoskeletal 8 (K2CB) is a type II cytoskeletal 8 keratin (K8) and usually coexpressed with K18 in normal epithelial cells. $\mathrm{K} 2 \mathrm{CB}$ protein is the oldest keratin among all identified and play significant role in regulation of cell cycle (Magin, Vijayaraj et al. 2007), protecting cells from stress $(\mathrm{Ku}$, Soetikno et al. 2003), injury and apoptosis (Caulin, Ware et al. 2000). Altered expression of K2CB protein is evidenced in lung (Hmmier, O'Brien et al. 2017), pancreatic, breast, renal, colorectal
(Yamamoto, Kudo et al. 2016), liver (Takegoshi, Okada et al. 2016), endometrial, ovarian and gastric cancer (Moll, Divo et al. 2008). K2CB protein was reported to be upregulated in breast cancer (Wu, Hancock et al. 2003; Hamler, Zhu et al. 2004), skin carcinoma (Larcher, Bauluz et al. 1992), bladder cancer cells (Lei, Zhao et al. 2013) compared to non cancerous counterparts. However downregulation of the protein in cisplatin resistant esophageal cell line and lung cancer has also been reported (Lai, Chan et al. 2016; Hmmier, O'Brien et al. 2017). In the present study, the protein was upregulated following the treatments of Cur alone and synergistic combined treatment of Ox with using bolus administration but downregulated after the treatment of Ox alone. The role of the protein remained unclear from this study due to inconsistency in the expression of $\mathrm{K} 2 \mathrm{CB}$ protein following different treatments. However, literature suggests that $\mathrm{K} 2 \mathrm{CB}$ protein contributes significantly in promoting colorectal cancer. Natural tumour active compound sulforaphene has been reported to give anticancer activity by supressing $\mathrm{K} 2 \mathrm{CB}$ protein; subsequently increased Fas concentration, decreased cFLIP activity and induced apoptosis (Yang, Ren et al. 2016). In a study on 25 patients of prostate cancer while receiving chemotherapy, level of K18 was monitored which is usually coexpressed with $\mathrm{K} 2 \mathrm{CB}$ protein. It was observed that circulatory K18 level was increased or decreased following adminstration of different drugs. The authors commented that cell death induced by chemotherapy does not inevitably depend on apoptosis, rather multiple mechanisms are involved (Ueno, Toi et al. 2005). Further study is required to ascertain the role of $\mathrm{K} 2 \mathrm{CB}$ protein in colorectal cancer. $\mathrm{K} 1 \mathrm{C} 18$ protein is a type I cytoskeletal 18 keratin (K18) protein which is highly conserved from teleosts to mammals. In 1950s the association of keratins including K1C18 protein was reported (Björklund and Björklund 1957; Björklund 1978). Later on it was discovered that $\mathrm{K} 1 \mathrm{C} 18$ protein is cleaved during apoptosis of normal and malignant cells at two sites into three fragments (Ueno, Toi et al. 2005). Upregulation of K1C18 protein in ovarian carcinoma (Wang, Kachman et al. 2004), cholangiocarcinoma (Srisomsap, Sawangareetrakul et al. 2004) and breast carcinoma (Wu, Hancock et al. 2003; Vergara, Simeone et al. 2013) has been observed in different studies. On the contrary, other studies showed downregulation of $\mathrm{K} 1 \mathrm{C} 18$ protein in several cancers including: prostate (O'Connell, Prencipe et al. 2012), cervical (Buddaseth, Göttmann et al. 2013) and colon carcinoma (Roblick, Hirschberg et al. 2004). One earlier studies suggested upregulation of $\mathrm{K} 1 \mathrm{C} 18$ protein is the good prognostic factor in breast cancer (Schaller, Fuchs et al. 1996). In the present study, the protein has been identified from Caco-2 cell line. K1C18 protein was upregulated following all the treatments indicating that the protein might act as apoptotic protein. The highest upregulation of the protein was caused with Cur alone treatment by a factor of 7.26. 
Whereas, synergistic treatment of Ox with Cur (bolus) caused 6.26 folds upregulation of K1C18 protein and Ox alone produced 2.6 times upregulation of the same protein. Similar to this study, oxaliplatin has been reported to cause upregulation of the protein in three different colorectal cancer cell lines (Yao, Jia et al. 2009). Moreover, the result of the present study is in accordance with earlier findings where maslinic acid (antitumour compound) downregulated the expression of $\mathrm{K} 1 \mathrm{C} 18$ protein significantly in HT-29 colon cancer cell line (Rufino-Palomares, Reyes-Zurita et al. 2013). Another in vivo study also revealed that elevated expression of the protein leads to suppression of malignancy in breast cancer cell (Bühler and Schaller 2005). It can be concluded that $\mathrm{K} 1 \mathrm{C} 18$ protein is an apoptotic protein and could be targeted to design newer anticancer drugs.

Heat shock cognate $71 \mathrm{kDa}$ protein (HSP7C) belongs to HSP70s class of molecular chaperones. In an earlier study, expression of HSP7C protein was found to be higher in cancerous cell lines compared to non-malignant cells e.g. lung, gastric, pancreatic, breast, cervical and endometrial cancer (Maeda, Ohguro et al. 2000). The level of HSP7C protein was found to be significantly increased in 95\% samples collected from the patients with colon cancer compared to the control group (Kubota, Yamamoto et al. 2010). The protein has been suggested as potential biomarker in neuroblastoma (Sandoval, Hoelz et al. 2006). In the present study, the protein was upregulated following all the treatments. Synergistic combined treatment of $\mathrm{Ox}$ with using bolus administration produced highest upregulation by a factor of 4.53 , followed by Cur alone treatment by the factor of 2 . It can be assumed that observed upregulation of HSP7C protein (following the treatments) and cell death might have a positive link. In both colorectal cell lines, synergistic combined treatments caused the highest amount of cell death. It could be the role of HSP7C protein as inducer of autophagy, promoting cytotoxicity by upregulating HSP7C. The protein has been reported to induced all three forms of autophagy: chaperone mediated autophagy, macroautoghagy and microautophagy (Stricher, Macri et al. 2013).

$78 \mathrm{kDa}$ glucose regulated protein or GRP78 acts a master regulator during endoplasmic stress. The primary responsibility of GRP78 protein is to translocate the proteins, controlling the folding and assembly of proteins, identification and deletion of misfolded proteins (Macias, Williamson et al. 2011). However, exposure of stress caused detachment of GRP78 protein from the mentioned transmembrane sensor proteins of endoplasmic reticulum and switches on the protective mechanism to avoid cell death (Lee 2007). Since cancer cells are continually subjected towards endoplasmic reticulum stress, GRP78 protein plays an integral role in survival of cancer cells and promote carcinogenesis. Literature suggests that GRP78 protein can also mediate chemotherapy resistance and inhibit apoptosis (Wang, Wey et al. 2009). Elevated expression of GRP78 protein has been documented in many cancers: liver (Shuda, Kondoh et al. 2003), breast (Lee, Nichols et al. 2006), lung (Fu and Lee 2006) and prostate (Miyake, Hara et al. 2000; Daneshmand, Quek et al. 2007). In the present study, the protein was upregulated following all the treatments in CACO-2 cell line. Highest upregulation was evidenced after the treatment with Cur alone by the factor of 2.2 whereas Ox alone did upregulation of the protein by 1.61 times. Synergistic combined treatment of Ox with Cur using bolus administration upregulated GRP78 protein by a factor of 1.56 . However, it was difficult to understand the relationship between observed upregulation of GRP78 protein following drug treatments and anticancer activity. PSB6 or proteasome subunit beta type- 6 is part of 20 S catalytic core of the proteasome. PSB6 protein modulates the cell cycle and many other processes through the breakdown of regulatory components and transcription factors (Frankland-Searby and Bhaumik 2012). Upregulation of PSB6 protein has been observed in lung cancer ( $\mathrm{Lu}$, Song et al. 2014), breast cancer (Canelle, Bousquet et al. 2006), thyroid cancer (Onda, Emi et al. 2004), hypoxia (Wang, Xu et al. 2013) and prostate cancer (Davalieva, Kostovska et al. 2015). In a study of HCT-116 colon cancer cell line, elevated expression of the protein also detected. In the present study, PSB6 protein was downregulated after the treatment with Ox alone in CACO-2 cell line. In contrast, upregulation of the protein was observed following the treatment with Cur alone in the same cell line. But PSB6 protein did not show significant changes in expression following synergistic combined treatment of Ox with Cur using bolus administration in CACO-2 cell line. This might be due to counterbalancing effect between $\mathrm{Ox}$ and Cur. In accordance to this study, PSB6 protein reported to be upregulated following treatment with curcumin in a breast cancer model (Fang, Chen et al. 2011). Further study is warranted to target PSB6 protein as anticancer drug target. Upregulation of PSB6 protein has been observed in lung cancer (Lu, Song et al. 2014), breast cancer (Canelle, Bousquet et al. 2006), thyroid cancer (Onda, Emi et al. 2004), hypoxia (Wang, Xu et al. 2013) and prostate cancer (Davalieva, Kostovska et al. 2015). In a study of HCT-116 colon cancer cell line, elevated expression of the protein also detected. In the present study, PSB6 protein was downregulated after the treatment with Ox alone in Caco-2 cell line. In contrast, upregulation of the protein was observed following the treatment with Cur alone in the same cell line. But PSB6 protein did not show significant changes in expression following synergistic combined treatment of Ox with Cur using bolus administration in Caco- 2 cell line. This might be due to counterbalancing effect between $\mathrm{Ox}$ and Cur. In accordance to this study, PSB6 protein reported to be upregulated following treatment with curcumin in a breast cancer model (Fang, Chen et 
al. 2011). Further study is warranted to target PSB6 protein as anticancer drug target.

IDHC or Isocitrate dehydrogenase [NADP] cytoplasmic is a protein belongs to oxidoreductase enzyme class. These enzymes are responsible for transfering electrons from oxidants to reductants which could be oxidases or dehydrogenases. Mutation of IDHC is evident in many cancers specially in glioma, which cause the enzyme to act in faster rate and more efficiently. However, controversy still exists regarding the role of IDHC in cancer, whether it provides oncogenic effects or tumour suppressive effects (Reitman and Yan 2010). In the present study, IDHC protein was identified from CACO-2 cell line. Following drug treatments either alone or in combination, the protein displayed uprgulation. Ox alone treatment caused the protein to be upregulated by 3 folds whereas Cur alone treatment did 1.8 folds upregulation. Synergistic combined treatment of Ox with Cur using bolus administration caused highest upregulation of IDHC by a factor of 5.75. It can be assumed from this study that IDHC protein might have proapoptotic action. To the best of my knowledge, this is the first report showing the changes in expression of IDHC protein in colorectal cancer cell following treatments with tumour active compounds. However, upregulation of IDHC protein has been documented in lung (Tan, Jiang et al. 2012), breast (Russell Hilt, Wittliff et al. 1973; Xu, Yan et al. 2010) and esophageal cancer cells (Qi, Chiu et al. 2005) compared to their noncancerous counterparts. A recent study has proved that, elevated expression of IDHC protein leads towards aggravation of tumour and therapy resistance in glioblastoma. The author suggested that inhibition of IDHC protein could be a promising therapeutic strategy against glioblastoma (Calvert 2017).

Cofilin1 is one of the traditional cofilins along with cofilin2 (muscle isoform-skeletal or cardiac) and destrins (available various tissues) (Bernstein and Bamburg 2010). Cofilin1 is responsible for actin polymerization and depolymerization through severing of filaments. At lower concentration cofilin1 favours severing of actin filaments and facilitate depolymerization, whereas at higher concentration actin nucleation and polymerization takes place (Shishkin, Eremina et al. 2016). Cofilin 1 facilitates the polymerization process of actin filaments by creating free pointed ends and providing actin monomers. Thus it is considered as essential regulator of cell motility and metastasis in malignant cells (Ghosh, Song et al. 2004). Moreover, cofilin1 plays vital role in restructuring of actin cytoskeleton when exposed towards variety of stimuli and stressed conditions. Other molecular level functions of cofilin1 includes: release of cytochrome C (Chua, Volbracht et al. 2003) and activation of phospholipase D1 (Han, Stope et al. 2007). Elevated expression of cofilin1 has been found in lung (Keshamouni, Michailidis et al.
2006), pancreatic (Sinha, Hütter et al. 1999), oral (Turhani, Krapfenbauer et al. 2006), kidney (Unwin, Craven et al. 2003), colorectal (Zhao, Liu et al. 2007) and ovarian cancer (Martoglio, Tom et al. 2000). However downregulation of cofilin1 is also evidenced in lymphoma, cervical, hepatic and colon cancer (Nebl, Meuer et al. 1996). In the present study, the protein was slightly upregulated after treatment with $\mathrm{Ox}$ alone and significantly upregulated following the treatment of synergistic combination of Ox with Cur using bolus administration in Caco-2 cell line. However, the protein was downregulated after the treatment with Cur alone in the same cell line. The variation in the expression of cofilin1 following drug treatments makes it difficult to ascertain the nature of the protein. The controversial nature of cofilin1 has been reported earlier as well (Tsai, Lin et al. 2015). The authors mention that, although strong evidence on upregulation of cofilin1 in multiple cancers is evident but overexpression of the protein may also cause suppression of cancer growth and invasion of cancer cells (Tsai, Lin et al. 2015). It was suggested that overexpression of cofilin1 cause cell cycle arrest but not induce apoptotic cell death. That is why strict control of cofilin1 expression is indispensable for normal functioning of cells (Tsai, Chiu et al. 2009).

\section{Conclusion}

In terms of synergistic outcomes, combination of $\mathrm{Ox}$ with Cur proved to be better than combination of Cs with Cur for all sequences of administration (0/0,0/4 and 4/0) against the tested four colorectal cell lines (HT-29, Caco-2, LIM-1215 and LIM2405). Ox in combination Cur demonstrated very high synergism against HT-29 and Caco-2 cell lines. Synergism from Ox with Cur was found at higher added concentrations $\left(\mathrm{ED}_{90}\right.$ and $\left.\mathrm{ED}_{75}\right)$ than lower added concentrations $\left(\mathrm{ED}_{50}\right)$ for all sequences of administration. Synergism from Ox with Cur may be associated with greater platinum $\varangle \mathrm{DNA}$ binding. Proteomics revealed that the elevated expressions of K1C18, GRP78, IDHC and Cofilin1 may be responsible for the synergistic activity obtained from the combination of Ox with Cur.

\section{Author Contributions}

Hana Bali carried out the lab work, carried out data analyses and drafted the manuscript. Jun Qing Yu contributed to development of experimental methods and assisted in data analyses. Philip Beale contributed to the discussion and writing of the manuscript. Fazlul Huq conceptualized the project, provided overall supervision including development of methods, data analyses and drafting of the manuscript.

\section{Acknowledgment}

Hana Bali is grateful to Government of Kingdom of Saudi Arabia for granting Postgraduate Scholarship. 


\section{Competing financial interests}

The author(s) declare no competing financial interests.

\section{References}

Al-Eisawi, Z., P. Beale, et al. (2013). "Carboplatin and oxaliplatin in sequenced combination with bortezomib in ovarian tumour models." Journal of ovarian research 6(1), 78. https://doi.org/10.1186/1757-2215-6-78

PMid:24209693 PMCid:PMC3826510

Al-Eisawi, Z., P. Beale, et al. (2016). "Changes in the in vitro activity of platinum drugs when administered in two aliquots." BMC cancer 16(1), 688

https://doi.org/10.1186/s12885-016-2731-1

PMid:27566066 PMCid:PMC5002105

Alam, M. N., J. Q. Yu, et al. (2020). "Cisplatin in combination with emetine and patulin showed dose and sequence dependent synergism against ovarian cancer." Synergy 10, 100060 .

https://doi.org/10.1016/j.synres.2019.100060

Alam, M. N., J. Q. Yu, et al. (2020). "Dose and sequence dependent synergism from the combination of oxaliplatin with emetine and patulin against colorectal cancer." Anti-Cancer Agents in Medicinal Chemistry (Formerly Current Medicinal Chemistry-Anti-Cancer Agents) 20(2), 264-273

https://doi.org/10.2174/1871520619666191021112042

PMid:31736447

Arzuman, L., P. Beale, et al. (2016). "Synthesis of tris (quinoline) monochloroplatinum (II) Chloride and its Activity Alone and in Combination with Capsaicin and Curcumin in Human Ovarian Cancer Cell Lines." Anticancer research 36(6), 2809-2818.

Bernstein, B. W. and J. R. Bamburg (2010). "ADF/cofilin: a functional node in cell biology." Trends in cell biology 20(4), 187-195.

https://doi.org/10.1016/j.tcb.2010.01.001

PMid:20133134 PMCid:PMC2849908

Björklund, B. (1978). Tissue polypeptide antigen (TPA): biology, biochemistry, improved assay methodology, clinical significance in cancer and other conditions, and future outlook. Laboratory testing for cancer, Karger Publishers. 22, 16-31.

https://doi.org/10.1159/000401148

Björklund, B. and V. Björklund (1957). "Antigenicity of pooled human malignant and normal tissues by cyto-immunological technique: presence of an insoluble, heat-labile tumor antigen." International Archives of Allergy and Immunology 10(3), 153-184. https://doi.org/10.1159/000228374

Buddaseth, S., W. Göttmann, et al. (2013). "Dysregulation of cell cycle control caused by overexpression of the oncogene pp32r1 (ANP32C) and the Tyr> His mutant pp32r1Y140H." Biochimica et Biophysica Acta (BBA)-Molecular Cell Research 1833(5), 1212-1221. https://doi.org/10.1016/j.bbamcr.2013.02.001

PMid:23403278

Bühler, H. and G. Schaller (2005). "Transfection of keratin 18 gene in human breast cancer cells causes induction of adhesion proteins and dramatic regression of malignancy in vitro and in vivo." Molecular cancer research 3(7), 365-371.
https://doi.org/10.1158/1541-7786.MCR-04-0117

PMid:16046547

Calvert, A. E. (2017). Cancer-Associated Isocitrate Dehydrogenase 1 Promotes Growth and Resistance to Targeted Therapies in the Absence of Mutation, Northwestern University.

Canelle, L., J. Bousquet, et al. (2006). "A proteomic approach to investigate potential biomarkers directed against membrane-associated breast cancer proteins." Electrophoresis 27(8), 1609-1616.

https://doi.org/10.1002/elps.200500712

PMid:16550497

Caulin, C., C. F. Ware, et al. (2000). "Keratin-dependent, epithelial resistance to tumor necrosis factor-induced apoptosis." The Journal of cell biology 149(1), 17-22.

https://doi.org/10.1083/jcb.149.1.17

PMid:10747083 PMCid:PMC2175089

Chou, T.-C. and P. Talalay (1984). "Quantitative analysis of dose-effect relationships: the combined effects of multiple drugs or enzyme inhibitors." Advances in enzyme regulation 22, 27-55.

https://doi.org/10.1016/0065-2571(84)90007-4

Chua, B. T., C. Volbracht, et al. (2003). "Mitochondrial translocation of cofilin is an early step in apoptosis induction." Nature cell biology 5(12), 1083.

https://doi.org/10.1038/ncb1070

PMid:14634665

Daneshmand, S., M. L. Quek, et al. (2007). "Glucose-regulated protein GRP78 is upregulated in prostate cancer and correlates with recurrence and survival." Human pathology 38(10), 1547-1552.

https://doi.org/10.1016/j.humpath.2007.03.014

PMid: 17640713

Davalieva, K., I. M. Kostovska, et al. (2015). "Proteomics analysis of malignant and benign prostate tissue by 2D DIGE/MS reveals new insights into proteins involved in prostate cancer." The Prostate 75(14), 1586-1600.

https://doi.org/10.1002/pros.23034

PMid:26074449

Dhara, S. (1970). "Cisplatin." Indian J. Chem 8:,123-134.

Fang, H., S. Chen, et al. (2011). "Proteomic identification of differentially expressed proteins in curcumin-treated MCF-7 cells." Phytomedicine 18(8-9), 697-703.

https://doi.org/10.1016/j.phymed.2010.11.012

PMid:21239154

Ferlay, J., I. Soerjomataram, et al. (2015). "GLOBOCAN 2012 v1. 0, Cancer Incidence and Mortality Worldwide: IARC Cancer Base No. 11. 2014." Available from: globocan. iarc. fr.

Frankland-Searby, S. and S. R. Bhaumik (2012). "The 26S proteasome complex: an attractive target for cancer therapy." Biochimica et Biophysica Acta (BBA)-Reviews on Cancer 1825(1), 64-76 https://doi.org/10.1016/j.bbcan.2011.10.003

PMid:22037302 PMCid:PMC3242858

Fu, Y. and A. S. Lee (2006). "Glucose regulated proteins in cancer progression, drug 
https://doi.org/10.4161/cbt.5.7.2970

PMid:16861902

Ghosh, M., X. Song, et al. (2004). "Cofilin promotes actin polymerization and defines the direction of cell motility." Science 304(5671), 743-746.

https://doi.org/10.1126/science.1094561

PMid:15118165

Hamler, R. L., K. Zhu, et al. (2004). "A two-dimensional liquid-phase separation method coupled with mass spectrometry for proteomic studies of breast cancer and biomarker identification." Proteomics 4(3), 562-577

https://doi.org/10.1002/pmic.200300606

PMid: 14997480

Han, L., M. B. Stope, et al. (2007). "Direct stimulation of receptor-controlled phospholipase D1 by phospho-cofilin." The EMBO journal 26(19), 4189-4202.

https://doi.org/10.1038/sj.emboj.7601852

PMid:17853892 PMCid:PMC2230846

Hmmier, A., M. E. O'Brien, et al. (2017). "Proteomic analysis of bronchoalveolar lavage fluid (BALF) from lung cancer patients using label-free mass spectrometry." BBA clinical 7, 97104.

https://doi.org/10.1016/j.bbacli.2017.03.001

PMid:28331811 PMCid:PMC5357681

Holch, J. W., I. Ricard, et al. (2017). "The relevance of primary tumour location in patients with metastatic colorectal cancer: a meta-analysis of first-line clinical trials." European Journal of Cancer 70, 87-98.

https://doi.org/10.1016/j.ejca.2016.10.007

PMid:27907852

Howells, L. M., S. Sale, et al. (2011). "Curcumin ameliorates oxaliplatin-induced chemoresistance in HCT116 colorectal cancer cells in vitro and in vivo." International journal of cancer 129(2), 476-486.

https://doi.org/10.1002/ijc.25670

PMid:20839263

Huq, F. (2015). Synergism from combination of targeted therapy with tumor active phytochemicals in ovarian tumor models and changes in protein expression, AACR. https://doi.org/10.1158/1538-7445.AM2015-3484

Huq, F., J. Q. Yu, et al. (2014). "Combinations of platinums and selected phytochemicals as a means of overcoming resistance in ovarian cancer." Anticancer research 34(1), 541-545.

Kang, J. H., H. S. Kang, et al. (2015). "Curcumin sensitizes human lung cancer cells to apoptosis and metastasis synergistically combined with carboplatin." Experimental Biology and Medicine 240(11), 1416-1425.

https://doi.org/10.1177/1535370215571881

PMid:25716014 PMCid:PMC4935310

Keshamouni, V. G., G. Michailidis, et al. (2006). "Differential protein expression profiling by ITRAQ- 2DLC-MS/MS of lung cancer cells undergoing epithelial-mesenchymal transition reveals a migratory/invasive phenotype." Journal of proteome research 5(5), 1143-1154. https://doi.org/10.1021/pr050455t

PMid: 16674103
Ku, N. O., R. M. Soetikno, et al. (2003). "Keratin mutation in transgenic mice predisposes to Fas but not TNF-induced apoptosis and massive liver injury." Hepatology 37(5), 1006-1014. https://doi.org/10.1053/jhep.2003.50181

PMid: 12717381

Kubota, H., S. Yamamoto, et al. (2010). "Increased expression of co-chaperone HOP with HSP9O and HSC70 and complex formation in human colonic carcinoma." Cell Stress and Chaperones 15(6), 1003-1011.

https://doi.org/10.1007/s12192-010-0211-0

PMid:20617406 PMCid:PMC3024075

Lai, K. K., K. T. Chan, et al. (2016). "14-3-3o confers cisplatin resistance in esophageal squamous cell carcinoma cells via regulating DNA repair molecules." Tumor Biology 37(2), 2127-2136.

https://doi.org/10.1007/s13277-015-4018-6

PMid:26346170

Larcher, F., C. Bauluz, et al. (1992). "Aberrant expression of the simple epithelial type II keratin 8 by mouse skin carcinomas but not papillomas." Molecular carcinogenesis 6(2), 112-121.

https://doi.org/10.1002/mc.2940060206

PMid:1382441

Lee, A. S. (2007). "GRP78 induction in cancer: therapeutic and prognostic implications." Cancer research 67(8), 3496-3499.

https://doi.org/10.1158/0008-5472.CAN-07-0325

PMid: 17440054

Lee, E., P. Nichols, et al. (2006). "GRP78 as a novel predictor of responsiveness to chemotherapy in breast cancer." Cancer research 66(16), 7849-7853. https://doi.org/10.1158/0008-5472.CAN-06-1660

PMid:16912156

Lei, T., X. Zhao, et al. (2013). "Discovery of potential bladder cancer biomarkers by comparative urine proteomics and analysis." Clinical genitourinary cancer 11(1), 56-62. https://doi.org/10.1016/j.clgc.2012.06.003

PMid:22982111

Levis, M., R. Pham, et al. (2004). "In vitro studies of a FLT3 inhibitor combined with chemotherapy: sequence of administration is important to achieve synergistic cytotoxic effects." Blood 104(4), 1145-1150.

https://doi.org/10.1182/blood-2004-01-0388

PMid: 15126317

Li, L., B. Ahmed, et al. (2007). "Liposomal curcumin with and without oxaliplatin: effects on cell growth, apoptosis, and angiogenesis in colorectal cancer." Molecular cancer therapeutics 6(4), 1276-1282.

https://doi.org/10.1158/1535-7163.MCT-06-0556

PMid:17431105

Lu, D., T. Lu, et al. (2013). "Drug combinations in cancer treatment." Clinical Experimental Pharmacology 3(4), 134.

https://doi.org/10.4172/2167-1052.1000e124

Lu, Z., Q. Song, et al. (2014). "Comparative proteomic analysis of anti-cancer mechanism by periplocin treatment in lung cancer cells." Cellular Physiology and Biochemistry 33(3), 859- 
https://doi.org/10.1159/000358658

PMid:24685647

Macias, A. T., D. S. Williamson, et al. (2011). "Adenosine-derived inhibitors of 78 kDa glucose regulated protein (Grp78) ATPase: insights into isoform selectivity." Journal of medicinal chemistry 54(12), 4034-4041.

https://doi.org/10.1021/jm101625x

PMid:21526763

Maeda, A., H. Ohguro, et al. (2000). "Aberrant expression of photoreceptor-specific calcium-binding protein (recoverin) in cancer cell lines." Cancer Research 60(7), 19141920.

Magin, T. M., P. Vijayaraj, et al. (2007). "Structural and regulatory functions of keratins." Experimental cell research 313(10), 2021-2032.

https://doi.org/10.1016/j.yexcr.2007.03.005

PMid:17434482

Martoglio, A.-M., B. Tom, et al. (2000). "Changes in tumorigenesis-and angiogenesis-related gene transcript abundance profiles in ovarian cancer detected by tailored high density cDNA arrays." Molecular Medicine 6(9), 750.

https://doi.org/10.1007/BF03402191

PMid:11071270 PMCid:PMC1949983

Mazumder, M. E. H., P. Beale, et al. (2012). "Epigallocatechin gallate acts synergistically in combination with cisplatin and designed trans-palladiums in ovarian cancer cells." Anticancer research 32(11), 4851-4860.

Miyake, H., I. Hara, et al. (2000). "Stress protein GRP78 prevents apoptosis induced by calcium ionophore, ionomycin, but not by glycosylation inhibitor, tunicamycin, in human prostate cancer cells." Journal of cellular biochemistry 77(3), 396-408.

https://doi.org/10.1002/(SICI)1097-4644(20000601)77:3<396::AID-JCB5>3.0.C0;2-5

Moll, R., M. Divo, et al. (2008). "The human keratins: biology and pathology." Histochemistry and cell biology 129(6), 705.

https://doi.org/10.1007/s00418-008-0435-6

PMid:18461349 PMCid:PMC2386534

Montopoli, M., E. Ragazzi, et al. (2009). "Cell-cycle inhibition and apoptosis induced by curcumin and cisplatin or oxaliplatin in human ovarian carcinoma cells." Cell proliferation 42(2), 195-206

https://doi.org/10.1111/j.1365-2184.2009.00585.x

PMid:19236381 PMCid:PMC6495462

Mosmann, T. (1983). "Rapid colorimetric assay for cellular growth and survival: application to proliferation and cytotoxicity assays." Journal of immunological methods 65(1-2), 55-63. https://doi.org/10.1016/0022-1759(83)90303-4

Nautiyal, J., S. S. Kanwar, et al. (2011). "Combination of dasatinib and curcumin eliminates chemo-resistant colon cancer cells." Journal of molecular signaling 6(1), 7.

https://doi.org/10.1186/1750-2187-6-7

PMid:21774804 PMCid:PMC3162943

Nebl, G., S. C. Meuer, et al. (1996). "Dephosphorylation of serine 3 regulates nuclear translocation of cofilin." Journal of Biological Chemistry 271(42), 26276-26280.

https://doi.org/10.1074/jbc.271.42.26276
Nessa, M. U., P. Beale, et al. (2012). "Combinations of resveratrol, cisplatin and oxaliplatin applied to human ovarian cancer cells." Anticancer research 32(1), 53-59.

Nessa, M. U., P. Beale, et al. (2012). "Studies on combination of platinum drugs cisplatin and oxaliplatin with phytochemicals anethole and curcumin in ovarian tumour models." Anticancer research 32(11), 4843-4850.

O'Connell, K., M. Prencipe, et al. (2012). "The use of LC-MS to identify differentially expressed proteins in docetaxel-resistant prostate cancer cell lines." Proteomics 12(13), 2115-2126.

https://doi.org/10.1002/pmic.201100489

PMid:22623417

Onda, M., M. Emi, et al. (2004). "Comprehensive gene expression profiling of anaplastic thyroid cancers with cDNA microarray of 25344 genes." Endocrine-related cancer 11(4), 843-854.

https://doi.org/10.1677/erc. 1.00818

PMid:15613457

Qi, Y., J. F. Chiu, et al. (2005). "Comparative proteomic analysis of esophageal squamous cell carcinoma." Proteomics 5(11), 2960-2971.

https://doi.org/10.1002/pmic.200401175

PMid:15986332

Reitman, Z. J. and H. Yan (2010). "Isocitrate dehydrogenase 1 and 2 mutations in cancer: alterations at a crossroads of cellular metabolism." Journal of the National Cancer Institute 102(13), 932-941.

https://doi.org/10.1093/jnci/djq187

PMid:20513808 PMCid:PMC2897878

Roblick, U., D. Hirschberg, et al. (2004). "Sequential proteome alterations during genesis and progression of colon cancer." Cellular and Molecular Life Sciences CMLS 61(10), 12461255.

https://doi.org/10.1007/s00018-004-4049-4

PMid: 15141310

Rufino-Palomares, E. E., F. J. Reyes-Zurita, et al. (2013). "Maslinic acid, a triterpenic antitumoural agent, interferes with cytoskeleton protein expression in HT29 human coloncancer cells." Journal of proteomics 83, 15-25.

https://doi.org/10.1016/j.jprot.2013.02.031

PMid:23499989

Russell Hilt, J., W. D. R. Wittliff, et al. (1973). "Studies on Certain Cytoplasmic Enzymes and Specific Estrogen Receptors in Human Breast Cancer and in Nonmalignant Diseases of the Breast1." CANCER RESEARCH 33, 2054-2062.

Sandoval, J. A., D. J. Hoelz, et al. (2006). "Novel peptides secreted from human neuroblastoma: useful clinical tools?" Journal of pediatric surgery 41(1), 245-251. https://doi.org/10.1016/j.jpedsurg.2005.10.048

PMid: 16410142

Schaller, G., I. Fuchs, et al. (1996). "Elevated keratin 18 protein expression indicates a favorable prognosis in patients with breast cancer." Clinical Cancer Research 2(11), 18791885. 
Shishkin, S., L. Eremina, et al. (2016). "Cofilin-1 and other ADF/cofilin superfamily members in human malignant cells." International journal of molecular sciences 18(1), 10.

https://doi.org/10.3390/ijms18010010

PMid:28025492 PMCid:PMC5297645

Shuda, M., N. Kondoh, et al. (2003). "Activation of the ATF6, XBP1 and grp78 genes in human hepatocellular carcinoma: a possible involvement of the ER stress pathway in hepatocarcinogenesis." Journal of hepatology 38(5), 605-614.

https://doi.org/10.1016/S0168-8278(03)00029-1

Sinha, P., G. Hütter, et al. (1999). "Increased expression of epidermal fatty acid binding


mass spectrometry and microsequencing of drug-resistant human adenocarcinoma of the pancreas." Electrophoresis 20(14), 2952-2960.

https://doi.org/10.1002/(SICI)1522-2683(19991001)20:14<2952::AID-

ELPS2952>3.0.CO;2-H

Srisomsap, C., P. Sawangareetrakul, et al. (2004). "Proteomic analysis of cholangiocarcinoma cell line." Proteomics 4(4), 1135-1144.

https://doi.org/10.1002/pmic.200300651

PMid:15048994

Stellwagen, N. C. (1998). DNA Gel Electrophoresis. Nucleic Acid Electrophoresis. D. Tietz. Berlin, Heidelberg, Springer Berlin Heidelberg: 1-53.

https://doi.org/10.1002/elps.1150190802

https://doi.org/10.1002/elps.1150191004

Stricher, F., C. Macri, et al. (2013). "HSPA8/HSC70 chaperone protein: structure, function, and chemical targeting." Autophagy 9(12), 1937-1954.

https://doi.org/10.4161/auto.26448

PMid:24121476

Takegoshi, K., E. Okada, et al. (2016). "Hepatocellular carcinoma and type 2 diabets mellitus: cytokeratin 8/18 expression in hepatocellular carcinoma and glycogen-storing hepatocytes." Hepatoma Res 2, 229-230.

https://doi.org/10.20517/2394-5079.2016.26

Tan, F., Y. Jiang, et al. (2012). "Identification of isocitrate dehydrogenase 1 as a potential diagnostic and prognostic biomarker for non-small cell lung cancer by proteomic analysis." Molecular \& Cellular Proteomics 11(2), M111. 008821.

https://doi.org/10.1074/mcp.M111.008821

PMid:22064513 PMCid:PMC3277750

Tsai, C.-H., S.-J. Chiu, et al. (2009). "Regulated expression of cofilin and the consequent regulation of p27kip1 are essential for G1 phase progression." Cell cycle 8(15), 2365-2374. https://doi.org/10.4161/cc.8.15.9072

PMid: 19556892

Tsai, C.-H., L.-T. Lin, et al. (2015). "Over-expression of cofilin-1 suppressed growth and invasion of cancer cells is associated with up-regulation of let-7 microRNA." Biochimica et Biophysica Acta (BBA)-Molecular Basis of Disease 1852(5), 851-861.

https://doi.org/10.1016/j.bbadis.2015.01.007

PMid:25597880

Turhani, D., K. Krapfenbauer, et al. (2006). "Identification of differentially expressed, tumor-associated proteins in oral squamous cell carcinoma by proteomic analysis." https://doi.org/10.1002/elps.200500510

PMid: 16568407

Ueno, T., M. Toi, et al. (2005). "Detection of epithelial cell death in the body by cytokeratin 18 measurement." Biomedicine \& pharmacotherapy 59, S359-S362. https://doi.org/10.1016/S0753-3322(05)80078-2

Unwin, R. D., R. A. Craven, et al. (2003). "Proteomic changes in renal cancer and co-ordinate demonstration of both the glycolytic and mitochondrial aspects of the Warburg effect." Proteomics 3(8), 1620-1632.

https://doi.org/10.1002/pmic.200300464

PMid:12923786

Vergara, D., P. Simeone, et al. (2013). "Comparative proteome profiling of breast tumor cell lines by gel electrophoresis and mass spectrometry reveals an epithelial mesenchymal transition associated protein signature." Molecular BioSystems 9(6), 1127-1138. https://doi.org/10.1039/C2MB25401H

PMid:23247860

Wang, H., M. T. Kachman, et al. (2004). "Comprehensive proteome analysis of ovarian cancers using liquid phase separation, mass mapping and tandem mass spectrometry: a strategy for identification of candidate cancer biomarkers." Proteomics 4(8), 2476-2495. https://doi.org/10.1002/pmic.200300763

PMid: 15274142

Wang, J., L. Xu, et al. (2013). "Proteomic analysis reveals that proteasome subunit beta 6 is involved in hypoxia-induced pulmonary vascular remodeling in rats." PloS one 8(7), e67942. https://doi.org/10.1371/journal.pone.0067942

PMid:23844134 PMCid:PMC3700908

Wang, M., S. Wey, et al. (2009). "Role of the unfolded protein response regulator GRP78/BiP in development, cancer, and neurological disorders." Antioxidants \& redox signaling 11(9), 2307-2316.

https://doi.org/10.1089/ars.2009.2485

PMid:19309259 PMCid:PMC2819800

Willett, W. C. and D. Trichopoulos (1996). "Nutrition and cancer: A summary of the evidence." Cancer Causes and Control 7(1), 178-180.

https://doi.org/10.1007/BF00115648

PMid:8850444

Wu, S. L., W. S. Hancock, et al. (2003). "An approach to the proteomic analysis of a breast cancer cell line (SKBR-3)." Proteomics 3(6), 1037-1046.

https://doi.org/10.1002/pmic.200300382

PMid:12833528

Xiao, B., X. Si, et al. (2015). "Co-delivery of camptothecin and curcumin by cationic polymeric nanoparticles for synergistic colon cancer combination chemotherapy." Journal of Materials Chemistry B 3(39), 7724-7733.

https://doi.org/10.1039/C5TB01245G

PMid:26617985 PMCid:PMC4662402

Xu, S.-G., P.-J. Yan, et al. (2010). "Differential proteomic analysis of a highly metastatic variant of human breast cancer cells using two-dimensional differential gel electrophoresis." Journal of cancer research and clinical oncology 136(10), 1545-1556.

https://doi.org/10.1007/s00432-010-0812-0 PMid.20155427 
Yamamoto, T., M. Kudo, et al. (2016). "Identification of aldolase A as a potential diagnostic biomarker for colorectal cancer based on proteomic analysis using formalin-fixed paraffinembedded tissue." Tumor Biology 37(10), 13595-13606.

https://doi.org/10.1007/s13277-016-5275-8

PMid:27468721 PMCid:PMC5097088

Yang, M., M. Ren, et al. (2016). "Sulforaphene inhibits hepatocellular carcinoma through repressing keratin 8 and activating anoikis." RSC Advances 6(74), 70326-70334.

https://doi.org/10.1039/C6RA11176A

Yao, Y., X.-Y. Jia, et al. (2009). "Comparative proteomic analysis of colon cancer cells in response to oxaliplatin treatment." Biochimica et Biophysica Acta (BBA)-Proteins and Proteomics 1794(10), 1433-1440.

https://doi.org/10.1016/j.bbapap.2009.06.005

PMid:19520192

Yu, T., Y. Yang, et al. (2015). "Circumvention of cisplatin resistance in ovarian cancer by combination of cyclosporin A and low-intensity ultrasound." European Journal of Pharmaceutics and Biopharmaceutics 91, 103-110.

https://doi.org/10.1016/j.ejpb.2015.02.003

PMid:25668779

Yunos, N. M., P. Beale, et al. (2011). "Synergism from sequenced combinations of curcumin and epigallocatechin-3-gallate with cisplatin in the killing of human ovarian cancer cells." Anticancer Research 31(4), 1131-1140.

Zhao, L., L. Liu, et al. (2007). "Differential proteomic analysis of human colorectal carcinoma cell lines metastasis-associated proteins." Journal of cancer research and clinical oncology 133(10), 771-782.

https://doi.org/10.1007/s00432-007-0222-0

PMid: 17503081

Zhu, S., V. Shanbhag, et al. (2017). "A Role for The ATP7A Copper Transporter in Tumorigenesis and Cisplatin Resistance." Journal of Cancer 8(11), 1952.

https://doi.org/10.7150/jca.19029

PMid:28819394 PMCid:PMC5559955 